\title{
p53 overexpression represses androgen-mediated induction of NKX3.1 in a prostate cancer cell line
}

\author{
Anli Jiang ${ }^{1 *}$, Chunxiao $\mathrm{Yu}^{1 *}$, \\ Pengju Zhang ${ }^{1}$, Weiwen Chen ${ }^{1}$, \\ Wenwen Liu ${ }^{1}$, Xiaoyan $\mathrm{Hu}^{1}$ and \\ Jianye Zhang ${ }^{1,2}$ \\ ${ }^{1}$ Department of Biochemistry \\ Medical School of Shandong University \\ Jinan 250012, China \\ ${ }^{2}$ Corresponding author: Tel, 86-531-88382092; \\ E-mail, Zhjy@sdu.edu.cn \\ *These authors contributed equally to this work.
}

\section{Accepted 11 October 2006}

Abbreviations: AR, androgen acceptor; ARE, androgen responsive element; CCS, charcoal-treated fetus cattle serum; EMSA, Electrophoresis mobility shift assay; p53 RE, p53 response element; p53mt, mutation type p53; p53wt, wild type p53; PIN, prostatic intraepithelial neoplasia

\begin{abstract}
Prostate cancer is a disease involving complicated multiple-gene alterations. Both $N K X 3.1$ and p53 are related to prostate cancer and play crucial roles in prostate cancer progression. However, little is known about the relationships and interactions between $p 53$ and $N K X 3.1$ in prostate cancer. We found that $N K X 3.1$ expression is down-regulated by over-expression of wild type (wt) p53 in prostate cancer LNCaP cells. NKX3.1 is down-regulated at both the mRNA and protein levels by p53 overexpression due to either transient transfection of exogenous $p 53$ or induction of endogenous p53. p53 over-expression represses androgen-induced transactivation of $N K X 3.1$ by inhibiting the promoter of the androgen acceptor $(A R)$ gene and by blocking AR-DNA binding activity. In addition, transfection with the p21 expression vector (pPSA-p21) showed that p21 does not reduce NKX3.1 expression, indicating that $N K X 3.1$ expression is not the result of nonspecific effects of cell growth arrest. Our results provide biochemical and cellular biologic evidence that NKX3.1 is down-regulated by p53 over-expression in prostate cancer cells.
\end{abstract}

Keywords: androgens; gene expression regulation;
NKX3.1 protein, human; prostate neoplasms; p53

\section{Introduction}

$N K X 3.1$ is an androgen regulated prostate-specific homeobox gene (Prescott et al., 1998) that is thought to be involved in prostate development and carcinogenesis (Bhatia-Gaur et al., 1999). Several different mouse models with Nkx3.1 dificiency have demonstrated abnormal ductal morphogenesis, hyperplasias, and PIN-like lesions in the prostate (Abdulkadir et al., 2002; Kim et al., 2002). Human NKX3.1 has been mapped to human chromosome $8 \mathrm{p} 21$, a locus that is frequently deleted in prostate cancer (Cher et al., 1996; Vocke et al., 1996; Dong, 2001; Asatiani et al., 2005). Loss of NKX3.1 expression has been shown to be associated with hormone-refractory prostate cancer and advanced tumor stage (Bowen et al., 2000); however, overexpression of $N K X 3.1$ in prostate cancer also has been reported ( $\mathrm{Xu}$ et al., 2000). No mutations in the NKX3.1 coding region have been found (Voeller et al., 1997; Ornstein et al., 2001). So far, the function of $N K X 3.1$ in prostate cancer has been shown to be complicated and the regulatory mechanisms of NKX3.1 expression are not well known.

The p53 tumor suppressor gene encodes a nuclear transcription factor that is activated and accumulates in cells in response to a variety of stresses inducing growth arrest or apoptosis. In prostate cancer, alterations in the $p 53$ gene are clearly associated with a progressive disease, including metastases to bone and androgen-independent growth (Navone et al., 1993; Aprikian et al., 1994; Eastham et al., 1995; Meyers et al., 1998; Burchardt et al., 2001). Recent evidence suggests that p53 is involved in androgen signaling. Cronauer et al. analyzed the effect of p53 on androgen signaling in 22Rv1 and LNCaP prostate cancer cells. Overexpression of $\mathrm{p} 53$ diminished the androgenic response in both cell lines. $A R, p 53$ and $N K X 3.1$ are all related to prostate cancer and play crucial roles in prostate cancer progression. However, little is known about their relationships and interactions in prostate cancer. We report that NKX3.1 expression is regulated by over-expression of wild type (wt) p53 in prostate cancer LNCaP cells and we provide evidence for the mechanisms that control down regulation of $N K X 3.1$ by p53 over-expression in 
Table 1. Primers used in PCR for mutagenesis analysis.

\begin{tabular}{ll}
\hline Names & \multicolumn{1}{c}{ Sequences of primers } \\
\hline PF + 8 & 5'GGCCTCGAGCGCACCGCTTTCACTTTC3' \\
PR-1032 & 5'CGCGAGCTCAAGGCAGGAGGATCACTTG3' \\
ID-507 & 5'TGCACCTACTCTTTGAGGTCGTAGATA 3' \\
ID-518 & 5'GACCTCAAAGAGTAGGTGCAGCCAGAC 3' \\
\hline
\end{tabular}

LNCaP cells.

\section{Materials and Methods}

\section{Construction of luciferase reporter plasmids}

The $\mathrm{pGL}_{3}-1040$ bp $N K X 3.1$ promoter was originally constructed by Jiang et al. (2004).

There is a $5^{\prime}$ half site of the p53 response element (p53 RE) between -517 and -508 upstream of the NKX3.1 gene. A p53 RE internal deletion from -517 to -508 was performed by a modified inverse PCR method. $\mathrm{pGL}_{3}-1040$ was used as the template and two pairs of primers (sequences shown in Table 1) were required for inverse PCR. The 5' flanking fragment was amplified using the primers PR-1032 and ID-518, and the 3' flanking fragment was amplified using the primers $\mathrm{PF}+8$ and ID-507. Inverse PCR was performed using pyrobest polymerase (TaKaRa, Japan) with denaturation at $94^{\circ} \mathrm{C}$ for $2 \mathrm{~min}$, followed by 35 cycles at $94^{\circ} \mathrm{C}$ for $30 \mathrm{~s}$, $62^{\circ} \mathrm{C}$ for $30 \mathrm{~s}$, and $72^{\circ} \mathrm{C}$ for $1 \mathrm{~min}$. The amplified $5^{\prime}$ and $3^{\prime}$ flanking fragments were purified and then ligated by PCR using pyrobest polymerase and the primers PR- 1032 and $\mathrm{PF}+8$ with denaturation at $94^{\circ} \mathrm{C}$ for $2 \mathrm{~min}$, annealing at $55^{\circ} \mathrm{C}$ for $30 \mathrm{~s}$, and extension at $72^{\circ} \mathrm{C}$ for $2 \mathrm{~min}$, followed by 35 cycles at $94^{\circ} \mathrm{C}$ for $30 \mathrm{~s}, 63^{\circ} \mathrm{C}$ for $30 \mathrm{~s}$, and $72^{\circ} \mathrm{C}$ for $1 \mathrm{~min}$. The resultant fragment was purified and cut with $\mathrm{Xhol}$ and Sacl, then inserted into the equivalent site of the $\mathrm{pGL}_{3}$-basic vector (Promega) to generate the p53 RE internal deletion mutant designated as $\mathrm{pGL}_{3}-\mathrm{p} 53 \mathrm{id}$.

\section{Cell culture}

The human prostate cancer cell line LNCaP was obtained from the American Type Culture Collection (ATCC). The line, which was established from lymph node metastasis of a prostate cancer patient, expresses the $A R, N K X 3.1$ and the wild type $p 53$ genes. LNCaP cells were routinely maintained in RPMI-1640 supplemented with $10 \%$ fetal bovine serum (Gibco) and antibiotics. Cells were cultured in RPMI-1640 containing $2 \%$ charcoal-treated fetus cattle serum, CCS (Gibco), and supplemented with
$10^{-8} \mathrm{~mol} / /$ of the synthetic androgen analog $\mathrm{R} 1881$ (New England Nuclear, Germany).

\section{Transient transfection}

For a luciferase reporter assay, LNCaP cells were seeded in 24-well plates and transfected at approximately $90 \%$ cell confluence. $\mathrm{pGL}_{3}$ constructs were cotransfected with pCMV-p53 (BD Biosciences, USA), with pCMV-p53 plus AR-expressing plasmid (Dr. Charles Young, Mayo Clinics, USA), with ARexpressing plasmid, or with vector lacking cDNA (as a control). The $\mathrm{pRL}-\mathrm{TK}$ vector (Promega) was used to correct for the transfection efficiency. Transfection was performed using lipofectimine ${ }^{\mathrm{TM}} 2000$ (Invetrigen) according to the manufacturer's instructions. After an incubation period of $6 \mathrm{~h}$ in RPMI-1640 without serum and antibiotics, the medium was changed to RPMI-1640 containing $2 \%$ CCS, with or without $10^{-8} \mathrm{~mol} / \mathrm{l}$ of $\mathrm{R} 1881$. The reporter activity was assessed after a $48 \mathrm{~h}$ incubation period using the Dual-Luciferase Reporter Assay System (Promega, Germany).

For RT-PCR and western blot analysis, LNCaP cells were seeded in $25 \mathrm{ml}$ bottles and transfected with $p C M V-p 53$, with pPSA- $p 21$ (kindly provided by Dr. Charles Young, Mayo Clinics, USA), or with pCMV-p53 plus $A R$-expressing plasmid. Vectors lacking p53 cDNA were used as a control. Cells were harvested for RT-PCR and western blot analysis $48 \mathrm{~h}$ after transfection.

\section{Dual-luciferase reporter assay}

The activities of firefly luciferase in $\mathrm{pGL}_{3}$ and of Renilla luciferase in pRL-TK were determined following the dual-luciferase reporter assay protocol recommended by Promega. The cells were rinsed twice with PBS buffer and cell lysates were prepared by manually scraping the cells from culture plates in the presence of $1 \times$ PLB (passive lysis buffer). Twenty $\mu$ of cell lysate was transferred into a luminometer tube containing $100 \mu$ of LAR II, and the firefly luciferase activity (M1) was measured first. The Renilla luciferase activity (M2) was then measured after adding $100 \mu$ of Stop \& Glo Reagent. The results were calculated and expressed as the ratio of M1/M2. Analyses were carried out twice or three times with double replicates. Data are presented as mean \pm S.D.

\section{Electrophoresis mobility shift assay (EMSA)}

Nuclear extracts from LNCaP cells were prepared according to the instructions for the nuclear extract kit (ACTIVE MOTIF) and quantified following the BCA method. Double-stranded ARE probes (sense 
sequence TGCAGAACAGCAAGTGCTAGC) were generated by annealing equimolar complementary oligonucleotides in TEN buffers at $95^{\circ} \mathrm{C}$ for $10 \mathrm{~min}$ with a slow cool-down period to room temperature. The double-stranded probes were labeled with digoxigenin (Roche, Germany) using terminal transferase (Roche, Germany). For EMSA, 32 pmol of labeled probes were incubated for $20 \mathrm{~min}$ at $25^{\circ} \mathrm{C}$ with $20 \mu \mathrm{g}$ of nuclear extract in the presence of $1 \mu \mathrm{g}$ of poly $(\mathrm{dl}-\mathrm{dC}), 0.1 \mu \mathrm{g}$ of poly L-lysine, $30 \mathrm{mmol} / \mathrm{l}$ $\mathrm{KCl}, 20 \mathrm{mmol} / \mathrm{l} \mathrm{HEPES}, 10 \mathrm{mmol} / \mathrm{l}\left(\mathrm{NH}_{4}\right)_{2} \mathrm{SO}_{4}, 1$ $\mathrm{mmol} / \mathrm{l}$ DTT, $0.2 \% \mathrm{v} / \mathrm{v}$ Tween 20 , and $1 \mathrm{mmol} / \mathrm{l}$ EDTA. Competition analyses were performed using EMSA conditions similar to those described above, except that the protein extracts were incubated with the probe in the presence of a 125-fold molar excess of unlabeled double-stranded oligonucleotides as a competitor. Subsequently, the DNA-protein complexes were separated from the free probes by electrophoresis on $5 \%$ non-denaturing polyacrylamide gel (Sigma). Electro-blotting and chemiluminescent detection were performed according to the instructions for the DIG Gel Shift Kit (Roche, Germany).

\section{Reverse transcription-PCR}

Total RNA was extracted from LNCaP cells using

A

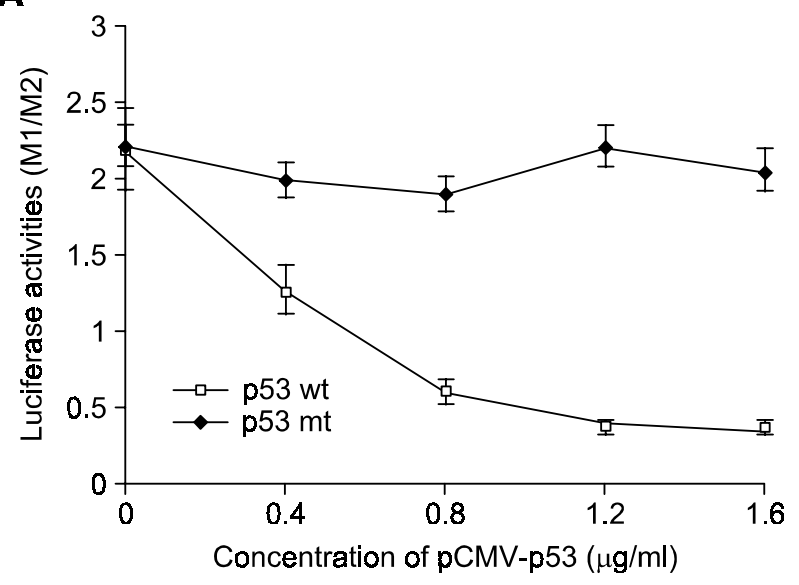

B

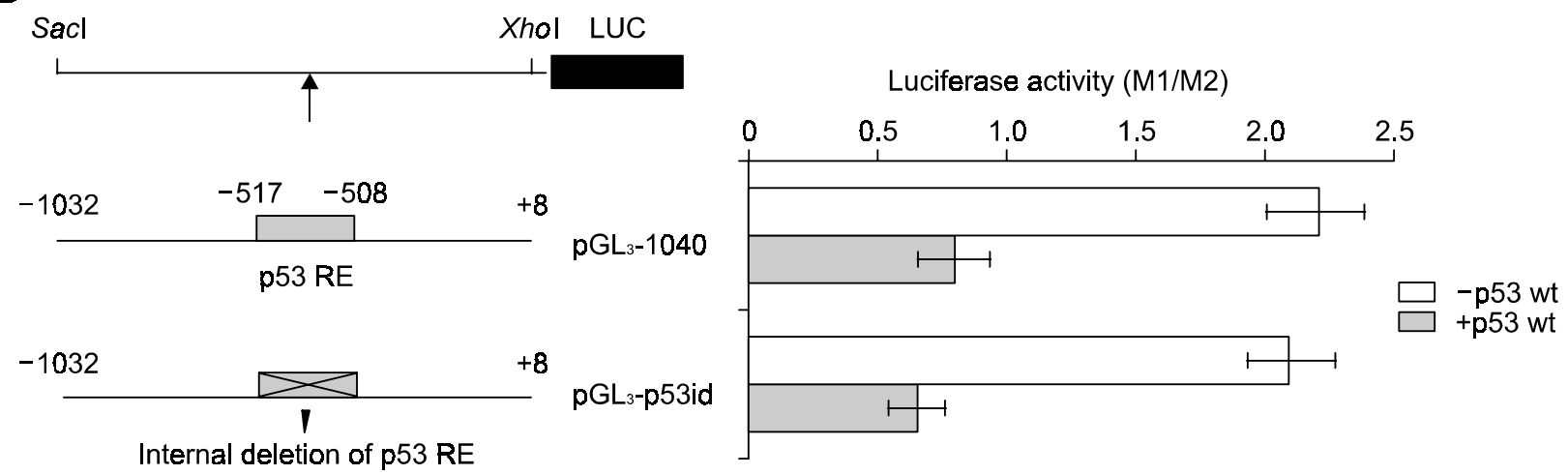

Figure 1. Effect of pCMV-p53 overexpression on NKX3.1 promoter activity. (A) LNCaP cells were seeded in 24-well plates and transfected with $0.8 \mu \mathrm{g}$ of $\mathrm{pGL}_{3}-1040$ and the indicated concentrations $(0-1.6 \mu \mathrm{g} / \mathrm{ml})$ of either pCMV-p53 wt or $p C M V-p 53 \mathrm{mt} .48 \mathrm{~h}$ after transfection, the cells were harvested for a dual-luciferase assay. pRL-TK vector was used to correct for the transfection efficiency. Results are expressed as the ratio of firefly luciferase activity (M1) in the $\mathrm{pGL}_{3}$ plasmid to Renilla luciferase activity (M2) in the pRL-TK plasmid. Data are presented as the mean of six individual values $\pm S D$. (B) PCR methods were used to construct the $\mathrm{pGL}_{3}-1040 \mathrm{bp} N K X 3.1$ promoter and its internal deletion mutant of $p 53$ RE. PCR produced fragments were separated and purified, then cut with both Xhol and Sacl and inserted into the equivalent site on the $p \mathrm{pL}_{3}$-basic vector to generate the constructs designated as $p \mathrm{GL}_{3}-1040$ and $p \mathrm{GL}_{3}-\mathrm{p} 53$ id. In the figure, $\mathrm{p} 53 \mathrm{RE}$ donates the $\mathrm{p} 53$ response element, and LUC donates the luciferase reporter gene. Either $\mathrm{pGL}_{3}-1040$ or $\mathrm{pGL}_{3}-\mathrm{p} 53$ id was co-transfected into $\mathrm{LNCaP}$ with, respectively, pCMV-p53 wt (+ p53 wt) or a vector lacking p53 cDNA (-p53 wt). $48 \mathrm{~h}$ after transfection, the cells were harvested for a dual-luciferase assay. Results are expressed as a relative luciferase activity (M1/M2). Data are presented as the mean of six individual values \pm SD. 
TRIzol reagent (MBI) following the manufacturer's instructions and expression of NKX3.1 mRNA was determined using RT-PCR with M-MuL $V$ reverse transcriptase (Invetrigen) in the presence of a random hexamer primer. PCR primers for NKX3.1 were 5'GTACCTGTCGGCCCCTGAACG3' (sense) and 3'GGACCAGAGGCACATATTGTCG5' (antisense). PCR primers for p53 were 5'TGTCATGGCGACTGTCCAGC3' (sense) and 5'GCTCGACGCTAGGATCTGAC3' (antisense). PCR conditions were denaturation at $94^{\circ} \mathrm{C}$ for $2 \mathrm{~min}$, followed by 25 cycles at $94^{\circ} \mathrm{C}$ for $30 \mathrm{~s}, 63^{\circ} \mathrm{C}$ (for $\mathrm{NKX} 3.1$ ) or $58^{\circ} \mathrm{C}$ (for p53) for $30 \mathrm{~s}$, and $72^{\circ} \mathrm{C}$ for $40 \mathrm{~s}$, followed by heating at $72^{\circ} \mathrm{C}$ for 8 min. A 550 bp segment of $\beta$-actin mRNA was amplified and used to normalize the quantity of the NKX3.1 mRNA in RT-PCR.

\section{SDS-polyacrylamide gel electrophoresis and western blot analysis}

LNCaP cells were harvested and lysed with cell lyses buffer $(50 \mathrm{mmol} / \mathrm{l}$ Tris $\cdot \mathrm{HCl}, \mathrm{pH} 8.0,150 \mathrm{mmol} / \mathrm{l}$ $\mathrm{NaCl}, 0.1 \%$ SDS, $100 \mu \mathrm{g} / \mathrm{ml}$ of PMSF, $1 \mu \mathrm{g} / \mathrm{ml}$ of aprotinin, and $1 \% \mathrm{NP}-40$ ). Cell extracts were quantified according to the BCA method. For Western blot analysis, $30 \mu \mathrm{g}$ of cell extract was separated on $10 \%$ SDS-PAGE, then electroblotted onto nitrocellulose membrane. After blocking and washing, the mem-

A

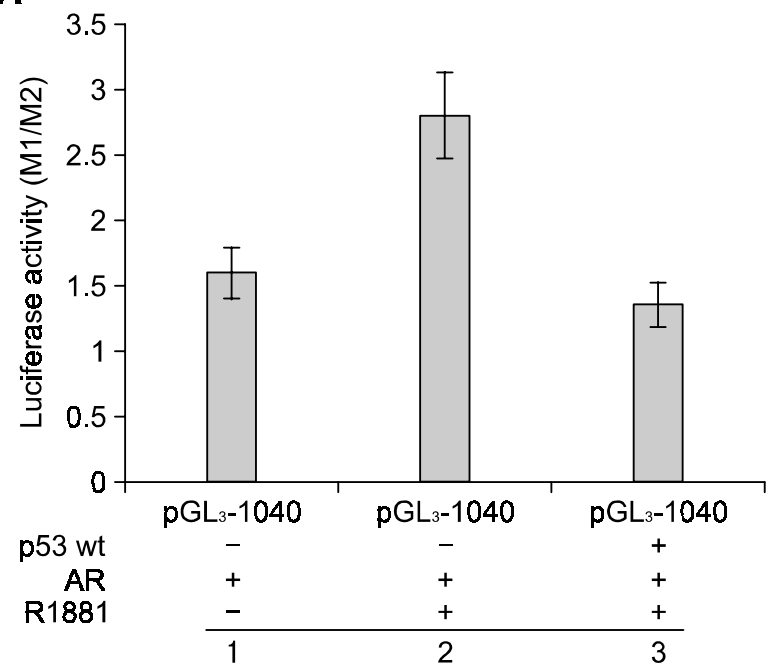

brane was exposed to specific anti-human NKX3.1 antibody (Research Diagnostics Inc) at $4^{\circ} \mathrm{C}$ for $12 \mathrm{~h}$, followed by incubation with peroxidase-labeled second antibody (Sigma) for $1 \mathrm{~h}$ at room temperature. Immunoreactive bands were visualized via enhanced chemiluminescence (Santa Cruz Biotech. Inc). $\beta$-tubulin (Sigma) was used to normalize the quantity of the protein on the blot.

\section{Results}

\section{Construction of luciferase reporter plasmids}

To observe the effects of p53 on NKX3.1 promoter activity, we constructed the $\mathrm{pGL}_{3}-1040$ bp $N K X 3.1$ promoter and its internal deletion mutant of a potential p53 response element (p53 RE). PCR methods were used in the construction and the related primers are listed in Table 1. A schematic depiction of the construction is shown in Figure 1B. All constructs were confirmed to be correct by restriction enzyme digestion and sequence analysis. $\mathrm{pGL}_{3}-\mathrm{p} 53 \mathrm{id}$ with p53 RE deleted from -517 to -508 showed no effect on NKX3.1 promoter activity (blank bar of pGL3-p53id vs. blank bar of pGL3-1040 in Figure 1B). However, the p53 inducible negative effect remained (grey bar of pGL3-p53id in Figure 1B), indicating that this p53 RE is probably not a functional
B

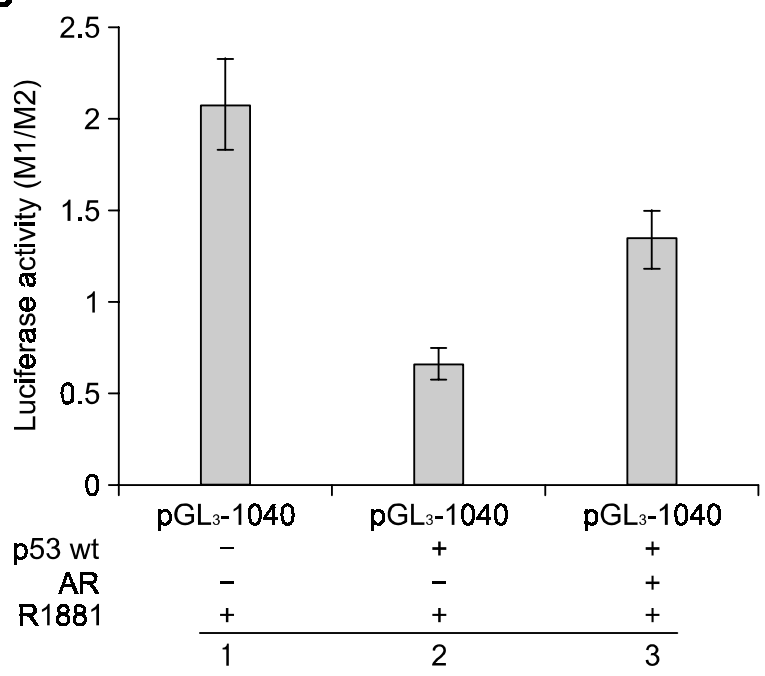

Figure 2. p53 over-expression repressed androgen-induced transactivation of the NKX3.1 promoter. LNCaP cells were seeded in 24-well plates with a $2 \%$ CCS medium for a luciferase reporter assay. (A) $0.6 \mu \mathrm{g}$ of $\mathrm{pGL}_{3}-1040$ was transfected into $\mathrm{LNCaP}$ cells with either $0.6 \mu \mathrm{g} / \mathrm{ml}$ of $A R$-expressing plasmid both without R1881 treatment (bar 1) and with R1881 $\left(10^{-8} \mathrm{~mol} / \mathrm{L}\right.$ ) treatment (bar 2), or with $0.6 \mu \mathrm{g}$ of $A R$-expressing plasmid plus $0.6 \mu \mathrm{g} / \mathrm{ml}$ of pCMV-p53 wt with R1881 treatment (bar 3 ). (B) $0.6 \mu \mathrm{g}$ of $p \mathrm{GL}_{3}-1040$ was transfected into LNCaP cells with R1881 $\left(10^{-8} \mathrm{~mol} / \mathrm{L}\right)$ treatment (bar 1), with $0.6 \mu \mathrm{g} / \mathrm{ml}$ of pCMV-p53 wt and R1881 $\left(10^{-8} \mathrm{~mol} / \mathrm{L}\right)$ treatment (bar 2), or with $0.6 \mu \mathrm{g}$ of AR-expressing plasmid

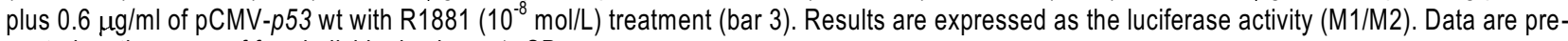
sented as the mean of four individual values $\pm \mathrm{SD}$. 
element in a $\mathrm{LNCaP}$ prostate cancer cell line.

\section{Inhibition of $N K X 3.1$ promoter activity by over-expression of wild p53}

To observe the effects of p53 on NKX3.1 promoter activity, LNCaP cells were seeded in 24-well plates and co-transfected with $0.8 \mu \mathrm{g}$ of $\mathrm{pGL}_{3}-1040$ and either $0-1.6 \mu \mathrm{g} / \mathrm{ml}$ of $p C M V-p 53 \mathrm{wt}$ or $\mathrm{pCMV}-p 53 \mathrm{mt}$ (BD Biosciences) using lipofectimine ${ }^{\mathrm{T} M}$ 2000. Cells were harvested for a dual-luciferase assay $48 \mathrm{~h}$ after transfection. The results (Figure $1 \mathrm{~A})$ showed that wild type p53 (p53 wt) and not mutant type p53 (p53 $\mathrm{mt}$ ) reduced $1040 \mathrm{bp}-\mathrm{NKX} 3.1$ promoter activity in a dose-dependent manner.

\section{p53 over-expression repressed androgen-induced transactivation of $N K X 3.1$}

There is a $5^{\prime}$ half site of the p53 response element (p53 RE) between -517 and -508 upstream of the NKX3.1 gene. However, the p53 RE internal deletion showed no effect on NKX3.1 promoter activity, indicating that induction of NKX3.1 is not directly regulated by p53 binding. NKX3.1 is an androgen-regulated homeobox gene, the expression of which can be regulated by androgen and androgen receptor activity. To investigate whether this inducible negative effect of p53 on NKX3.1 promoter is related to $A R$ activity, $\mathrm{pGL}_{3}-1040$ was co-transfected into LNCaP cells with pCMV-p53 wt and an ARexpressing vector. The results (Figure 2) showed

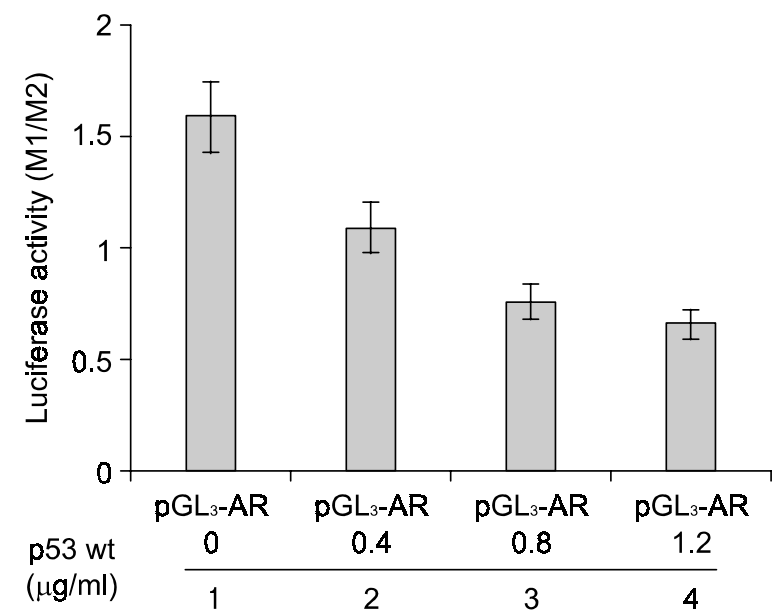

Figure 3. Inhibition of $A R$ promoter activity by $p 53$ over-expression. LNCaP cells were seeded in 24-well plates and co-transfected with $0.8 \mu \mathrm{g}$ of the $A R$ promoter-reporter plasmid $\left(\mathrm{pGL}_{3}-\mathrm{AR}\right.$ ) and $0,0.4$, 0.8 , or $1.2 \mu \mathrm{g} / \mathrm{ml}$ (the grey bars from 1-4) of pCMV-p53 wt treated with $10^{-8} \mathrm{~mol} / \mathrm{l}$ of R1881. $48 \mathrm{~h}$ after transfection the cells were harvested for a luciferase reporter assay. Results are expressed as the relative luciferase activity (M1/M2). Data are presented as the mean of four individual values $\pm \mathrm{SD}$. that p53 over-expression repressed androgen-induced transactivation of the NKX3.1 promoter (bar 3 in Figure $2 \mathrm{~A}$ ), and that $\mathrm{AR}$ overexpression can relieve the negative effect of p53 on NKX3.1 promoter activity (bar 3 in Figure $2 B$ ), indicating that $A R$ is probably involved in the negative effect of p53 on the $N K X 3.1$ promoter and that p53 represses androgen-induced transactivation of NKX3.1.

To detect the effect of p53 over-expression on $A R$ gene promoter activity, pCMV-p53 wt was co-transfected into LNCaP cells with the $\mathrm{pGL}_{3}-A R$ promoter (supplied by Dr. Charles Young, Mayo Clinic) using lipofectimine ${ }^{\mathrm{TM}}$ 2000. The result (Figure 3) showed that $A R$ promoter activity was reduced by $\mathrm{p} 53$ over-expression in a dose-dependent manner based in a luciferase reporter assay.

To detect the effect of $p 53$ over-expression on AR binding activity with ARE, EMSA was performed using a DIG-labeled ARE probe and nuclear extracts from LNCaP cells that were transfected with pCMVp53 wt. The result (Figure 4) showed that p53 overexpression inhibited the AR binding activity with

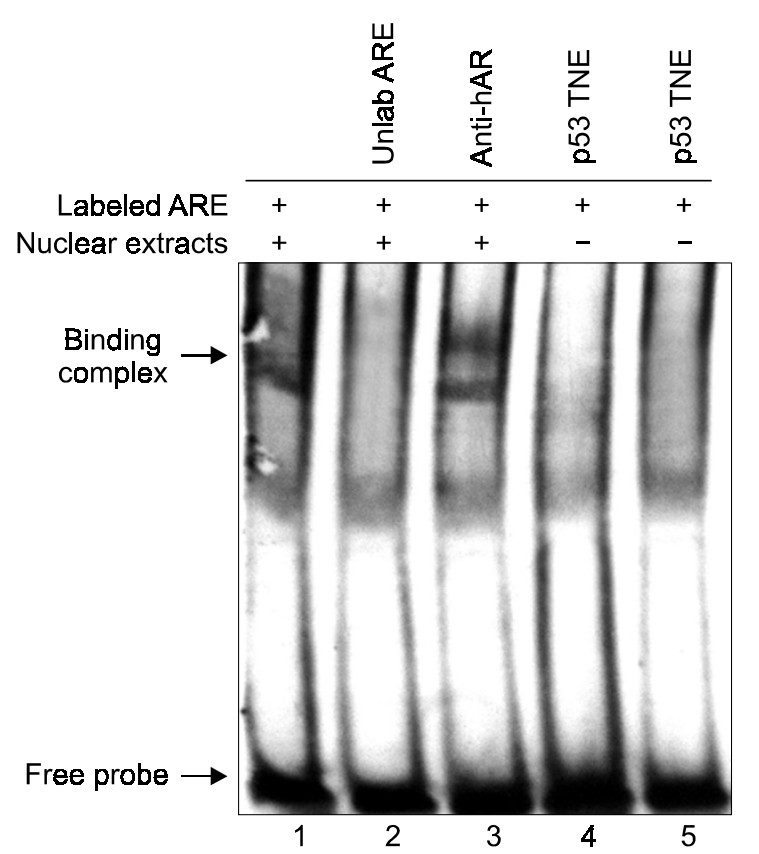

Figure 4. Assay of AR binding activity with ARE in EMSA. LNCaP cells were transfected with $1.0 \mu \mathrm{g} / \mathrm{ml}$ of $A R$-expressing plasmid either with or without pCMV-p53 wt, then treated with $10^{-8} \mathrm{~mol} / / \mathrm{l}$ of R1881. Nuclear extracts from LNCaP cells were tested for AR DNA binding in EMSA. $32 \mathrm{pmol}$ of DIG-labeled ARE was incubated with $20 \mu \mathrm{g}$ of nuclear extract from cells transfected with $1.0 \mu \mathrm{g} / \mathrm{ml}$ of $A R$-expressing plasmid plus either $0.8 \mu \mathrm{g} / \mathrm{ml}$ of the $\mathrm{pCMV}$ plasmid lacking CDNA (lane 1-3), or $0.8 \mu \mathrm{g} / \mathrm{ml}$ of pCMV-p53 wt (lane 4), or $1.2 \mu \mathrm{g} / \mathrm{ml}$ of pCMV-p53 wt (lane 5). Competition was carried out with a 125-fold excess of unlabeled ARE (lane 2). Anti-hAR was used in supershift (lane 3). Note that p53 TNE denotes p53 treated nuclear extracts. ARE represents the androgen response element. 


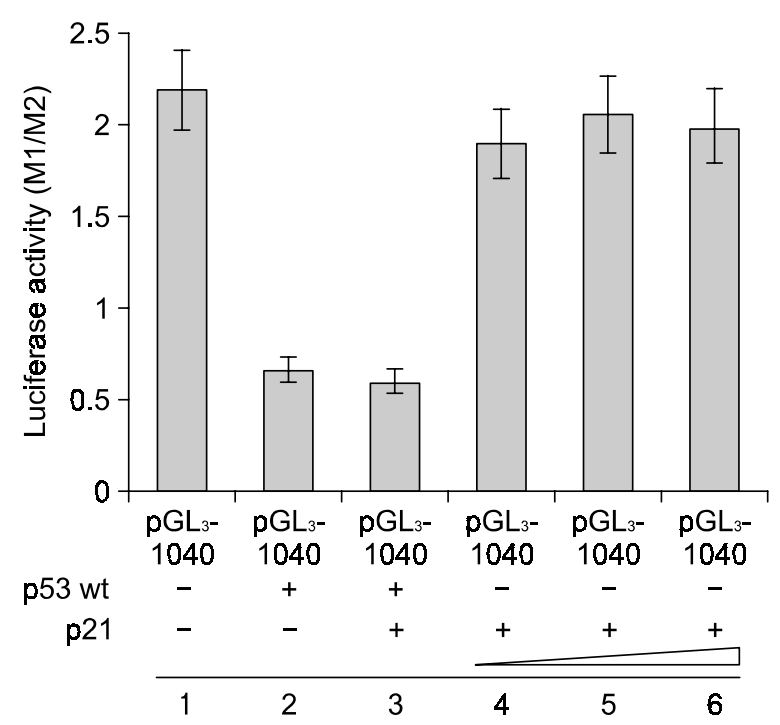

Figure 5. Effects of p21 on NKX3.1 promoter activity. LNCaP cells were seeded in 24-well plates and co-transfected with $0.8 \mu \mathrm{g}$ of $\mathrm{pGL}_{3}-1040$ and $0.8 \mu \mathrm{g} / \mathrm{ml}$ of $\mathrm{pCMV}$ lacking CDNA (bar 1), with $0.8 \mu \mathrm{g}$ of $\mathrm{pGL}_{3}-1040$ and $0.8 \mu \mathrm{g} / \mathrm{ml}$ of pCMV-p53 wt (bar 2), with $0.8 \mu \mathrm{g}$ of $\mathrm{pGL}_{3}-1040$ and $0.8 \mu \mathrm{g} / \mathrm{ml}$ of $\mathrm{pCMV}-\mathrm{p} 53$ wt plus $0.4 \mu \mathrm{g} / \mathrm{ml}$ of pPSA-p21 (bar 3), or with $0.8 \mu \mathrm{g}$ of $\mathrm{pGL}_{3}-1040$ and $0.4,0.8,1.2$ $\mu \mathrm{g} / \mathrm{ml}$ of pPSA-p21 without pCMV-p53 (bars 4-6). After a $48 \mathrm{~h}$ incubation period with RPMI-1640 containing $2 \%$ CCS and $10^{-8} \mathrm{~mol} / \mathrm{l}$ of R1881, the cells were harvested for a luciferase reporter assay. Results are expressed as luciferase activities (M1/M2). Data are presented as the mean of four individual values \pm SD.

ARE (lane 4, 5 in Figure 4).

p53 over-expression probably repressed androgen-induced transactivation of $N K X 3.1$ by inhibiting the promoter of the $A R$ gene and by blocking AR-DNA binding activity.

\section{Down-regulation of $N K X 3.1$ by $p 53$ over-expression is not mediated by $\mathrm{p} 21$ and is not a result of cell growth arrest}

p53 expression can lead to induction of the downstream target gene $p 21^{\text {waf1/cip } 1}$ that is an inhibitor of the cell cycle and that causes cell growth arrest. To demonstrate whether $N K X 3.1$ down-regulation is mediated by this p53-p21 pathway, LNCaP cells were co-transfected with $\mathrm{pGL}_{3}-1040$ and a $p 21$ expressing vector (pPSA-p21). The results (Figure $5)$ showed that p21 did not reduce $N K X 3.1$ promoter activity (bars 4-6). Only p53 reduced NKX3.1 promoter activity (bars 2,3 ). These results indicate that the $N K X 3.1$ promoter was probably specifically inhibited by $p 53$ over-expression and was not inhibited as a result of cell growth arrest.
A

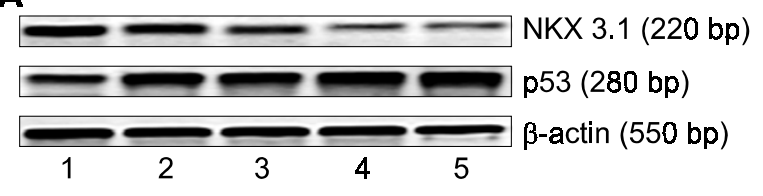

B

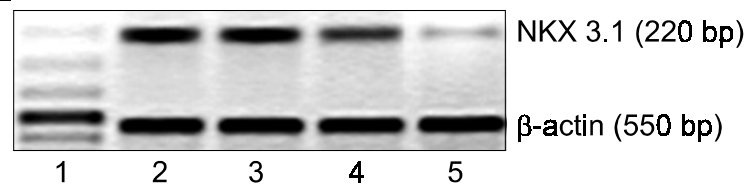

Figure 6. Effects of p53 over-expression on NKX3.1 mRNA expression in LNCaP cells. LNCaP cells were transfected with the indicated plasmids for $48 \mathrm{~h}$. RT-PCR was carried out to analyze NKX3.1 mRNA expression. (A) 1, control with pCMV lacking CDNA transfection; $2-5$, transfection with $0.5,1.0,2.0$, or $4.0 \mu \mathrm{g} / \mathrm{ml}$ of pCMV-p53 wt; (B) 1, DNA marker; 2, control with pCMV lacking cDNA transfection; 3 , transfection with $4.0 \mu \mathrm{g} / \mathrm{ml}$ of pPSA-p21; 4 , transfection with $2.0 \mu \mathrm{g} / \mathrm{ml}$ of pCMV-p53 wt plus $2.0 \mu \mathrm{g} / \mathrm{ml}$ of $A R$-expressing plasmid; 5 , treatment with UV irradiation. $\beta$-actin was used as an internal control.

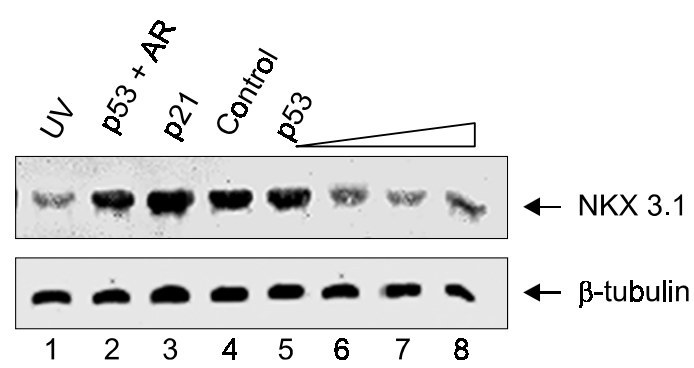

Figure 7. Effects of p53 over-expression on NKX3.1 protein expression in $\mathrm{LNCaP}$ cells. $\mathrm{LNCaP}$ cells were transfected with the indicated plasmids for $48 \mathrm{~h}$. Western blot analysis was carried out to analyze NKX3.1 protein expression. Lane 1, treatment with UV irradiation; 2, transfection with $2.0 \mu \mathrm{g} / \mathrm{ml}$ of pCMV-p53 wt plus $2.0 \mu \mathrm{g} / \mathrm{ml}$ of AR-expressing plasmid; 3, transfection with $4.0 \mu \mathrm{g} / \mathrm{ml}$ of pPSA-p21; 4, control transfected with pCMV lacking the cDNA vector; $5-8$, transfection with $0.5,1.0,2.0$, or $4.0 \mu \mathrm{g} / \mathrm{ml}$ of pCMV-p53 wt. $\beta$-tubulin was used as an internal control for protein loading and transfer efficiency.

\section{p53 over-expression down-regulates androgen-mediated NKX3.1 expression}

RT-PCR and a Western blot assay were performed to investigate the effects of $p 53$ over-expression on NKX3.1 expression. LNCaP cells were cultured in 25 $\mathrm{ml}$ bottles and treated with $0.5-4.0 \mu \mathrm{g} / \mathrm{ml}$ of $\mathrm{pCMV}$ p53 wt (lanes 2-5 in Figure 6A and lanes 5-8 in Figure 7 ), with $4.0 \mu \mathrm{g} / \mathrm{ml}$ of pPSA-P21 plasmid (lane 3 in Figure 6B and lane 3 in Figure 7), or with 2.0 $\mu \mathrm{g} / \mathrm{ml}$ of pCMV-p53 wt plus $2.0 \mu \mathrm{g} / \mathrm{ml}$ of $A R$-expressing plasmid (lane 4 in Figure $6 \mathrm{~B}$ and lane 2 in Figure 
7). In addition, LNCaP cells were exposed to UV irradiation to induce endogenous p53 expression (lane 5 in Figure $6 \mathrm{~B}$ and lane 1 in Figure 7). As shown in Figures 6 and 7, the expressions of NKX3.1 mRNA and protein were down-regulated by p53 over-expression in a dose-dependent manner. Endogenous p53 induced by UV irradiation also inhibited NKX3.1 mRNA and protein expression. To determine whether p21 and AR are involved in p53 negative regulation of $N K X 3.1, \mathrm{LNCaP}$ cells were treated with pPSA-p21, or with pCMV-p53 wt plus $A R$-expressing plasmid. Results showed that $\mathrm{p} 21$ did not down-regulate $N K X 3.1$ expression (lane 3 in Figure $6 B$ and lane 3 in Figure 7 ) while AR relieved p53 inhibition of NKX3.1 expression (lane 4 in Figure $6 \mathrm{~B}$ and lane 2 in Figure 7). These results indicate that $N K X 3.1$ expression is probably specifically reduced by $\mathrm{p} 53$ and mediated by $A R$, and is not the result of nonspecific effects of the cell growth arrest mediated by $\mathrm{p} 21$.

\section{Discussion}

p53 is a transcription factor that recognizes a specific consensus DNA sequence consisting of two copies of a 10-bp motif, 5'-PuPuPuC(A/T)(T/A)GPyPyPy- 3'. Wild-type p53 (but not mutants) efficiently binds to this sequence and transactivates expression of the target genes (El-Deiry et al., 1992; 1993; Kastan et al., 1992; Okamoto et al., 1994; Miyashita et al., 1995). p53 can also repress a wide variety of cellular and viral promoters that lack p53 binding sites, including $c$-fos, $b c l-2$, and the insulin-like growth factor I receptor (Santhanam et al., 1991; Kley et al., 1992; Subler et al., 1992; Donehower et al., 1993; Miyashita et al., 1994; Werner et al., 1996). Furthermore, p53 can bind to the TATAbinding protein and repress promoter activity (Seto et al., 1992; Liu et al., 1993). p53 also interacts with other transcription factors, including Sp1 (Borellini et al., 1993), the CCAAT-binding factor (Agoff et al., 1993), the cAMP response element-binding protein (Desdouets et al., 1996), and glucocorticoid receptors (Maiyar et al., 1997). These observations indicate that p53 interacts with the transcription machinery to modulate gene expression. We found that NKX3.1 expression is down-regulated by over-expression of wild type p53. NKX3.1 is downregulated at both the mRNA and protein levels by p53 over-expression due to either transient transfection of exogenous $p 53$ or induction of endogenous $p 53$ in LNCaP cells.

There is increasing evidence that p53 directly regulates androgen signaling. The p53 protein interacts with several steroid receptors, including AR
(Yu et al., 1997a; 1997b; Sengupta et al., 2001; Shenk et al., 2001). AR is a member of the nuclear receptor superfamily of transcription factors (Evans, 1988; O'Malley, 1990) and is activated either by its androgen ligand or in a ligand-independent manner (Brinkmann et al., 1999; Feldman and Feldman, 2001; Grossmann et al., 2001; Culig, 2004). Subsequently, the activated receptor homodimerizes and interacts with specific androgen response elements in the regulatory regions of androgen target genes, resulting in stimulation of gene expression. Over-expression of p53 down-regulates the androgenic response in prostate cancer cells (Cronauer et al., 2004) and p53 blocks AR DNA binding by disrupting the amino- to carboxyl-terminal (N-to-C) interaction, which is thought to be responsible for the homodimerization of this receptor (Shenk et al., 2001). Over-expression of $p 53$ in LNCaP cells probably results in a dramatic decrease in AR-transactivation of the androgen-inducible gene. NKX3.1 is an androgen-regulated homeobox gene in the prostate, the expression of which can be regulated by androgen and androgen receptor activity. We found that p53 over-expression represses androgen-induced transactivation of NKX3.1 (Figure 2) by inhibiting the $A R$ promoter (Figure 3 ) and by blocking AR-DNA binding activity (Figure 4), indicating that $A R$ is probably involved in the negative effects of p53 on the NKX3.1 promoter.

There is a potential p53 RE between -517 and -508 upstream of the NKX3.1 gene shown in the TRANSFAC database. To determine whether this p53 RE is a functional element for mediation of p53 inducible regulation of the $N K X 3.1$ promoter, we constructed a mutant ( $\left.\mathrm{pGL}_{3}-\mathrm{p} 53 \mathrm{id}\right)$ of the $N K X 3.1$ promoter with p53 RE deleted from -517 to -508 of NKX3.1 (Figure 1B). Results showed that $\mathrm{pGL}_{3}-$ p53id had no effect on NKX3.1 promoter activity and still retained a p53 inducible negative effect on the NKX3.1 promoter (Figure 1B), indicating that this p53 RE is not a functional element in the LNCaP prostate cancer cell line.

DNA-damaging agents are inducers of p53 expression that lead to induction of downstream target genes, such as $p 21^{\text {waf } 1 / \text { cip } 1}$, which encode a $\mathrm{G}_{1}$ cyclin/CDK inhibitor that causes cell growth arrest (Levine 1997). To determine whether NKX3.1 downregulation is mediated by this $\mathrm{p} 53-\mathrm{p} 21$ pathway, LNCaP cells were transfected with either $p 53 \mathrm{wt}$ or the $p 21$ expressing vector pPSA-p21. p21 transfection had no effect on NKX3.1 promoter activity (Figure 5) and NKX3.1 expression (Figures 6 and 7), indicating that $N K X 3.1$ was specifically inhibited by p53 over-expression and not by cell growth arrest. In addition, to determine whether NKX3.1 expression is inducible in response to DNA damage, LNCaP cells 
were UV-irradiated and the effects of endogenous p53 on NKX3.1 expression were analyzed. As shown in Figures 6 and 7, UV irradiation treatment reduced NKX3.1 expression in LNCaP cells containing endogenous wild type p53.

It would be interesting to investigate the mechanism for indirect-repression of the NKX3.1 gene by p53. Our data show that $N K X 3.1$ expression is down-regulated at both the mRNA and protein levels by $p 53$ over-expression in $\mathrm{LNCaP}$ cells. The negative effects of p53 on NKX3.1 may be related to p53 over-expression repressing androgen-induced transactivation of $N K X 3.1$ by inhibiting the promoter of the androgen acceptor gene, and by blocking of the AR-DNA binding activity. Furthermore, this negative effect of p53 on NKX3.1 is not the result of cell growth arrest mediated by $\mathrm{p} 21$. Both $N K X 3.1$ and $p 53$ are related to prostate cancer and play crucial roles in prostate cancer progression. In prostate cancer, alterations in the $p 53$ tumor suppressor gene are clearly associated with a progressive disease. Loss of $N K X 3.1$ expression (Bowen et al., 2000) or NKX3.1 over-expression (Xu et al., 2000) has been shown to be associated with hormonerefractory prostate cancer and advanced tumor stage. Further molecular biological and clinical investigations will be needed to interpret the relationship between $p 53$ and $N K X 3.1$ in prostate cancer.

\section{Acknowledgement}

The authors are grateful to Dr. Charles Young (Mayo Clinic, USA) for providing pPSA-p21, $\mathrm{pGL}_{3}-A R$, and the $A R$-expressing plasmid that were used in this study. This work was supported by grants from the Natural Science Foundation of Shandong Province (No.Y2004C26) and the National Natural Science Foundation (No. 30470820 and No. 30371564).

\section{References}

Abdulkadir SA, Magee JA, Peters TJ, Kaleem Z, Naughton CK, Humphrey PA, Milbrandt J. Conditional loss of Nkx3.1 in adult mice induces prostatic intraepithelial neoplasia. Mol Cell Biol 2002;22:1495-503

Agoff SN, Hou J, Linzer DIH, Wu B. Regulation of the human hsp70 promoter by p53. Science 1993;259: 84-7

Aprikian AG, Sarkis AS, Fair WR, Zhang ZF, Fuks Z, Cordon-Cardo $\mathrm{C}$. Immunohistochemical determination of p53 protein nuclear accumulation in prostatic adenocarcinoma. J Urol 1994;151:1276-80

Asatiani E, Huang WX, Wang A, Rodriguez Ortner E, Cavalli LR, Haddad BR, Gelmann EP. Deletion, methylation, and expression of the NKX3.1 suppressor gene in primary human prostate cancer. Cancer Res 2005;65:1164-73
Bhatia-Gaur R, Donjacour AA, Sciavolino PJ, Kim M, Desai N, Young P, Norton CR, Gridley T, Cardiff RD, Cunha GR, Abate-Shen C, Shen MM. Roles for Nkx3.1 in prostate development and cancer. Genes Dev 1999;13:966-77

Borellini F, Glazer RI. Induction of Sp1-p53 DNA-binding heterocomplexes during granulocyte/macrophage colonystimulating factor-dependent proliferation in human erythroleukemia cell line TF-1. J Biol Chem 1993;268:7923-8

Bowen C, Bubendorf L, Voeller HJ, Slack R, Willi N, Sauter G, Gasser TC, Koivisto P, Lack EE, Kononen J, Kallioniemi OP, Gelmann EP. Loss of NKX3.1 expression in human prostate cancers correlates with tumor progression. Cancer Res 2000;60:6111-5

Brinkmann AO, Blok LJ, de Ruiter PE, Doesburg P, Steketee $\mathrm{K}$, Berrevoets CA, Trapman J. Mechanisms of androgen receptor activation and function. J Steroid Biochem Mol Biol 1999;69:307-13

Burchardt M, Burchardt T, Shabsigh A, Ghafar M, Chen MW, Anastasiadis A, de la Taille A, Kiss A, Buttyan R. Reduction of wild type p53 function confers a hormone resistant phenotype on LNCaP prostate cancer cells. Prostate 2001;48:225-30

Cher ML, Bova GS, Moore DH, Small EJ, Carroll PR, Pin SS, Epstein JI, Isaacs WB, Jensen RH. Genetic alterations in untreated metastases and androgen-independent prostate cancer detected by comparative genomic hybridization and allelotyping. Cancer Res 1996;56:3091-102

Cronauer MV, Schulz WA, Burchardt T, Ackermann R, Burchardt M. Inhibition of p53 function diminishes androgen receptor-mediated signaling in prostate cancer cell lines. Oncogene 2004;23:3541-9

Culig Z. Androgen receptor cross-talk with cell signalling pathways. Growth Factors 2004; 22:179-84

Desdouets C, Ory C, Matesic G, Soussi CB, Sobczak-Thepot J. ATF/CREB site mediated transcriptional activation and p53 dependent repression of the cyclin A promoter. FEBS Lett 1996;385:34-8

Donehower LA, Bradley A. The tumor suppressor p53. Biochim Biophys Acta 1993;1155:181-205

Dong JT. Chromosomal deletions and tumor suppressor genes in prostate cancer. Cancer Metastasis Rev 2001; 20:173-93

Eastham JA, Stapleton AM, Gousse AE, Timme TL, Yang G, Slawin KM, Wheeler TM, Scardino PT, Thompson TC. Association of p53 mutations with metastatic prostate cancer. Clin Cancer Res 1995;1:1111-8

El-Deiry WS, Kern S, Pietenpol JA, Kinzler KW, Vogelster B. Definition of a consensus binding site for p53. Nat Genet 1992;1:45-9

El-Deiry WS, Tokino T, Veculescu VE, Levy DB, Parsons R, Trent J, Lin D, Mercer WE, Kinzler KW, Vogelster B. WAF1, a potential mediator of p53 tumor suppression. Cell 1993; 75:817-25

Evans RM. The steroid and thyroid hormone receptor superfamily. Science 1988;240:889-95

Feldman BJ, Feldman D. The development of andro- 
gen-independent prostate cancer. Nat Rev Cancer 2001; 1:34-4

Grossmann ME, Huang H, Tindall DJ. Androgen receptor signaling in androgen-refractory prostate cancer. J Nat Cancer Ins 2001;93:1687-97

Jiang AL, Zhang JY, Young C, Hu XY, Wang YM, Liu ZF, Hao ML. Molecular cloning and characterization of human homeobox gene NKX3.1 promoter. Acta Biochim Biophys Sin (Shanghai) 2004;36:64-7

Kastan MB, Zhan Q, el-Deiry WS, Carrier F, Jacks T, Walsh WV, Plunkett BS, Vogelstein B, Fornace AJ Jr. A mammalian cell cycle checkpoint pathway utilizing p53 and GADD45 is defective in ataxia-telangiectasia. Cell 1992;71:587-97

Kim MJ, Bhatia-Gaur R, Banach-Petrosky WA, Desai N, Wang Y, Hayward SW, Cunha GR, Cardiff RD, Shen MM, Abate-Shen C. Nkx3.1 mutant mice recapitulate early stages of prostate carcinogenesis. Cancer Res 2002;62:2999-3004

Kley N, Chung RY, Fay S, Loeffler JP, Seizinger BR. Repression of the basal c-fos promoter by wild-type p53. Nucleic Acids Res 1992;20:4083-7

Levine AJ. p53, the cellular gatekeeper for growth and division. Cell 1997;88:323-31

Liu X, Miller CW, Koeffler PH, Berk AJ. The p53 activation domain binds the TATA box-binding polypeptide in Holo-TFIID, and a neighboring p53 domain inhibits transcription. Mol Cell Biol 1993;13:3291-300

Maiyar AC, Phu PT, Huang AJ, Firestone GL. Repression of glucocorticoid receptor transactivation and DNA binding of a glucocorticoid response element within the serum/glucocorticoid-inducible protein kinase (sgk) gene promoter by the p53 tumor suppressor protein. Mol Endocrinol 1997;11: 312-29

Meyers FJ, Gumerlock PH, Chi SG, Borchers H, Deitch AD, deVere White RW. Very frequent p53 mutations in metastatic prostate carcinoma and in matched primary tumors. Cancer 1998;83:2534-9

Miyashita T, Harigai M, Hanada M, Reed JC. Identification of a p53-dependent negative response element in the bcl-2 gene. Cancer Res 1994;54:3131-5

Miyashita T, Reed JC. Tumor suppressor p53 is a direct transcriptional activator of the human bax gene. Cell 1995;80:293-9

Navone NM, Troncoso P, Pisters LL, Goodrow TL, Palmer JL, Nichols WW, von Eschenbach AC, Conti CJ. p53 protein accumulation and gene mutation in the progression of human prostate carcinoma. J Natl Cancer Inst 1993;85:1657-69

Okamoto K, Beach D. Cyclin G is a transcriptional target of the p53 tumor suppressor protein. EMBO J 1994;13:4816-22

O'Malley B. The steroid receptor superfamily: more excitement predicted for the future. Mol Endocrinol 1990;4:363-69
Ornstein DK, Cinquanta M, Weiler S, Duray PH, Emmert-Buck MR, Vocke CD, Linehan WM, Ferretti JA. Expression studies and mutational analysis of the androgen regulated homeobox gene NKX3.1 in benign and malignant prostate epithelium. J Urol 2001;165:1329-34

Prescott JL, Blok L, Tindall DJ. Isolation and androgen regulation of the human homeobox cDNA, NKX3.1. Prostate 1998;35:71-80

Santhanam U, Ray A, Sehgal PB. Repression of the interleukin 6 gene promoter by p53 and the retinoblastoma susceptibility gene product. Proc Natl Acad Sci USA 1991;88:7605-9

Sengupta S, Wasylyk B. Ligand-dependent interaction of the glucocorticoid receptor with p53 enhances their degradation by Hdm2. Genes Dev 2001;15:2367-80

Seto E, Usheva A, Zambetti GP, Momand J, Hokoshi N, Weinmann R, Levine AJ, Shenk T. Wild-type p53 binds to the TATA-binding protein and represses transcription. Proc Natl Acad Sci USA 1992;89:12028-32

Shenk JL, Fisher CJ, Chen SY, Zhou XF, Tillman K, and Shemshedini L. p53 represses androgen-induced transactivation of prostate-specific antigen by disrupting hAR amino- to carboxyl-terminal interaction. J Biol Chem 2001;276: 38472-79

Subler MA, Martin DW, Deb S. Inhibition of viral and cellular promoters by human wild-type p53. J Virol 1992;66:4757-62

Vocke CD, Pozzatti RO, Bostwick DG, Florence CD, Jennings SB, Strup SE, Duray PH, Liotta LA, Emmert-Buck MR, Linehan WM. Analysis of 99 microdissected prostate carcinomas reveals a high frequency of allelic loss on chromosome 8p12-21.Cancer Res 1996;56:2411-6

Voeller HJ, Augustus M, Madike V, Bova GS, Carter KC, Gelmann EP. Coding region of NKX3.1, a prostate-specific homeobox gene on 8 p21, is not mutated in human prostate cancers. Cancer Res 1997;57:4455-9

Werner H, Karnieli E, Rauscher F III, LeRoith D. Wild-type and mutant p53 differentially regulate transcription of the insulin-like growth factor I receptor gene. Proc Natl Acad Sci USA 1996;93:8318-23

Xu LL, Srikantan V, Sesterhenn IA, Augustus M, Dean R, Moul JW, Carter KC, Srivastava S. Expression profile of an androgen regulated prostate specific homeobox gene NKX3.1 in primary prostate cancer. J Urol 2000;163:972-9

Yu C, Yap N, Chen D, Cheng S. Modulation of hormonedependent transcriptional activity of the glucocorticoid receptor by the tumor suppressor p53. Cancer Lett 1997a; 116:191-6

Yu CL, Driggers P, Barrera-Hernandez G, Nunez SB, Segars $\mathrm{JH}$, Cheng $\mathrm{S}$. The tumor suppressor $\mathrm{p} 53$ is a negative regulator of estrogen receptor signaling pathways. Biochem Biophys Res Commun 1997b;239:617-20 